\title{
How much care does a shrub-feeding hairstreak butterfly, Satyrium spini (Lepidoptera: Lycaenidae), need in calcareous grasslands?
}

\author{
Franz LÖFFLER, GREgor STUHLDREHER and ThOMAS FARTMANN* \\ Department of Community Ecology, Institute of Landscape Ecology, University of Münster, Robert-Koch-Straße 28, \\ 48149 Münster, Germany
}

Key words. Lycaenidae, Satyrium spini, clear-cut, conservation management, egg-laying, microclimate, oviposition preference, Rhamnus cathartica

\begin{abstract}
Many butterfly target species are associated with early successional stages of grasslands. The Blue-spot Hairstreak, Satyrium spini (Denis \& Schiffermüller, 1775), is a target species of grasslands. However, it feeds on Common Buckthorn (Rhamnus cathartica), which is associated with late successional stages of grasslands. If $S$. spini would also be restricted to late seral stages, there might be a management dilemma due to the contrasting requirements of $S$. spini and other target species. The aim of this study was to determine the oviposition preference of $S$. spini in calcareous grasslands, and to give management recommendations to promote this species. Therefore, we studied the oviposition microhabitats of $S$. spini at three representative patches of the Diemel Valley (Central Germany) by comparing environmental conditions on occupied and control host plants. In total we surveyed 1,889 host plants. Altogether we found 148 batches of S. spini on them containing 396 eggs. Most of the eggs were on plants that grew under the warmest conditions. Females preferred to lay eggs on small $(<1.3 \mathrm{~m})$ shrubs of Rh. cathartica fully exposed to the sun growing on steep south- and west-facing slopes. This butterfly showed no difference in its preference for bushes growing in hedges or solitarily. About $80 \%$ of the batches of eggs were laid on the upper surface of a twig fork close to the surface of the ground $(<1 \mathrm{~m})$. Our study showed that $S$. spini is a species characteristic of mid-successional stages of calcareous grasslands. The survival of suitable habitats for S. spini depends on regular management. To achieve this we recommend traditional rough grazing with sheep and goats, which creates open grasslands with small Rhamnus plants. In addition, the shrubs in tall hedges bordering calcareous grasslands should be subjected to cutting on a rotating basis.
\end{abstract}

\section{INTRODUCTION}

Calcareous grasslands are one of the most species-rich habitats in Europe, harbouring many threatened plant and animal species (Willems, 1990; Steffan-Dewenter \& Tscharntke, 2000). As it is a semi-natural habitat it needs to be managed. Intensification of land use, abandonment and afforestation are responsible for the marked reduction in the area and quality of semi-natural grasslands over the last few decades (Van Dijk, 1991; Kahmen et al., 2002; WallisDeVries et al., 2002). Because of their value as biodiversity hotspots in our landscapes and strongly endangered status they are protected under the EU Habitats Directive (Ssymank et al., 1998).

Butterflies are a characteristic insect group of calcareous grasslands with about $50 \%$ of all native European butterflies occurring in these nutrient-poor grasslands (Van Swaay, 2002). Butterflies respond rapidly to environmental changes and are excellent bioindicators (Watt \& Boggs, 2003; Van Swaay et al., 2006). During recent decades, butterflies have undergone a substantial decline throughout Europe. Today, butterflies are ranked among the most threatened groups of animals (Thomas et al., 2004; Van Swaay et al., 2006).

The susceptibility of many butterflies to environmental fluctuations is associated with their low mobility, long life span and the pronounced habitat specificity of the pre-adult stages (Thomas et al., 2001; García-Barros \& Fartmann, 2009). Especially egg-hibernating species, such as most Central European hairstreaks, are characterized by longer life spans of the immature stages compared with those of the adults (Fartmann \& Hermann, 2006). The larvae of many species feed only on a single genus of plants or even a single species (monophagy; Dennis et al., 2004). In addition, only a small fraction of the host plants within a patch are suitable for the development of eggs and larvae (Dennis et al., 2006). Microclimate is among the most important factors determining the successful development of the immature stages (Shreeve, 1986; Thomas et al., 1998; Roy \& Thomas, 2003).

Many species of grassland butterflies are at their northern range limit in Central and North-western Europe and are associated with early successional stages (Thomas, 1993, Thomas et al., 1998, Möllenbeck et al., 2009, Kadlec et al., 2010). The Blue-spot Hairstreak, Satyrium spini (Denis \& Schiffermüller, 1775), is a characteristic species of calcareous grasslands (Ebert \& Rennwald, 1991; Fartmann, 2004; Hermann, 2007) and is categorized as threatened in Germany (Reinhardt \& Bolz, in press). Thus, it is a target species for conservation planning (Koschuh et al., 2005) and is at the northern border of its distribution in northern Germany (Fartmann, 2004). Its main host plant in Central Europe is a shrub,

\footnotetext{
* Author for correspondence: fartmann@uni-muenster.de
} 


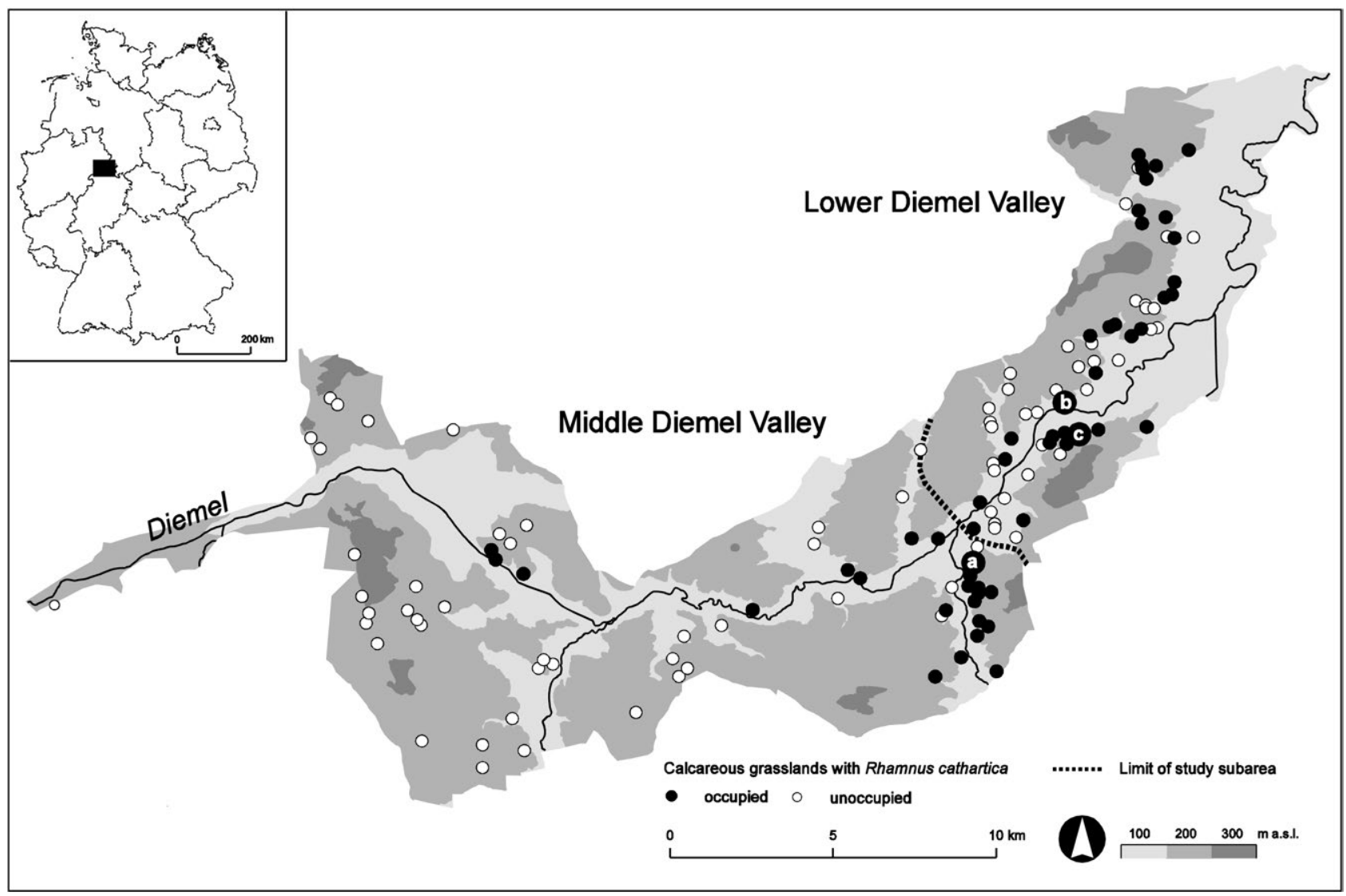

Fig. 1. Diemel Valley study area and subareas, location in north-western Germany (inset), distribution of Satyrium spini (winter 2009/2010) and locations of the patches studied (a) Wiegenfuß, (b) Bunter Berg and (c) Eberschützer Klippen.

the Common Buckthorn (Rhamnus cathartica) (Hermann, 2007). Because Rh. cathartica is a stress-tolerant competitor (Grime et al., 2007), reaching a height of 1-3 m and is a species characteristic of thermophilous shrubberies (Oberdorfer, 2001) it is reasonable to assume that S. spini is restricted to the late successional stages of grasslands. If this is the case, there might be a management dilemma due to the contrasting requirements of S. spini and target species associated with early successional stages. However, the evidence indicates that S. spini avoids Rhamnus plants growing in late successional stages of grasslands with extensive scrub encroachment or high-growing hedges and, instead, prefers earlier seral stages of grasslands (Weidemann, 1982; Koschuh et al., 2005; Hermann, 2007). However, there are no detailed analyses of its preference for particular microhabitats.

The aim of this study was to determine the oviposition preferences of the shrub-feeding hairstreak butterfly $S$. spini in Central European calcareous grasslands and provide management recommendations for promoting this target species. In particular we addressed the following questions:

(i) Which environmental parameters explain egg-laying preferences best, and why?

(ii) How should grasslands be managed to favour the Blue-spot Hairstreak butterfly?

\section{MATERIALS AND METHODS}

\section{Study organism}

Satyrium spini (Lepidoptera: Lycaenidae) is distributed from Southwestern and Central Europe to Western Asia (Ebert \& Rennwald, 1991; Kudrna, 2002). In Central Europe it is restricted to regions with warm summers (Ebert \& Rennwald, 1991; Beneš et al., 2002), where it occurs in shrubby calcareous grasslands and sunny clearings in woodland (Ebert \& Rennwald, 1991; Fartmann, 2004; Hermann, 2007). Satyrium spini is univoltine, with a flight period ranging from mid-June to the beginning of August (Ebert \& Rennwald, 1991; Fartmann, 2004). By far the most important host plant of this butterfly in Central Europe (Hermann, 2007) and the only one in the study area (Fartmann, 2004), is the Common Buckthorn (Rhamnus cathartica). In contrast to most other Central European hairstreaks, $S$. spini lays its eggs in small batches. It hibernates as an egg (Fartmann \& Hermann, 2006). Thus, searching for eggs on the host plant in winter is the easiest way to survey this species. The larvae feed on the leaves of its host plant (Hermann, 2007).

\section{Study area}

The study area (hereafter called Diemel Valley) is about 390 $\mathrm{km}^{2}$ in extent and is located in Central Germany along the border between the federal states of North Rhine-Westphalia and Hesse $\left(51^{\circ} 22^{\prime} \mathrm{N} / 8^{\circ} 38^{\prime} \mathrm{E}\right.$ and $\left.51^{\circ} 38^{\prime} \mathrm{N} / 9^{\circ} 25^{\prime} \mathrm{E}\right)$ at an altitude of $100-610 \mathrm{~m}$ a.s.l. (Fig. 1). The climate is suboceanic and varies greatly according to altitude. The Upper Diemel Valley (300-610 $\mathrm{m}$ a.s.1.) is the coldest and wettest part of the valley, with mean temperatures of $6.5-8^{\circ} \mathrm{C}$ and an annual precipitation of 700-1,000 mm. The Middle and Lower Diemel Valley $(<300$ $\mathrm{m}$ a.s.l.) in the eastern part of the study area have a relatively 
mild climate with less than $800 \mathrm{~mm}$ annual precipitation and an average annual temperature of up to $9^{\circ} \mathrm{C}$ (Fartmann, 2004).

The Diemel Valley is the largest area of calcareous grassland in the northern half of Germany and consists of a dense network of patches of grassland (Fartmann, 2004, 2006) a large percentage of which are Natura 2000 sites (Fartmann, 2004). Moreover, the Middle and Lower Diemel Valley is the northernmost German Prime Butterfly Area (Van Swaay \& Warren, 2003). The Diemel Valley is at the north-western range limit of $S$. spini in Central Europe. Within the study area, the species is restricted to the mild Middle and Lower Diemel Valley (Fig. 1; Fartmann, 2004).

\section{Experimental design}

Oviposition microhabitats of $S$. spini were studied in one patch in the Middle Diemel Valley ("Wiegenfuß", WF) and two patches in the Lower Diemel Valley ("Bunter Berg", BB; "Eberschützer Klippen”, EK) (Fig. 1). These patches were representative of the full range of environmental conditions (aspect, slope, number of host plants) present in the study area. Patch size ranged from 2.2-7 ha (Table 1). The patch WF was the only one that was grazed regularly (paddock) and the two other patches were irregularly (EK) or not grazed (BB) (Table 1).

In March 2010, all the Rh. cathartica plants were systematically checked for egg batches (cf. Hermann, 2007). Searching of a host plant ceased if no batch or no other batch was found within 10 min. We counted the number of batches, and eggs per batch, at each oviposition site.

In order to analyse oviposition preferences and to save time, we measured particular environmental parameters in the immediate area of two thirds of the batches of eggs detected. We used a systematic approach, so that every third batch was not analysed. Oviposition height and height of the host plant were measured. The number of host plants in a circular area of $100 \mathrm{~m}^{2}$ around each host plant was counted. Aspect and slope were recorded using a compass with an inclinometer. A horizontoscope after Tonne (1954) was used to collect data regarding daily potential duration of sunshine during the peak of flight activity in July. If host plants grew within hedges, batch orientation along hedge sides was measured using a compass. Batch position on the host plant (stem, twig and top or bottom of twig fork) and bark structure (smooth or rough-barked) were recorded.

For comparing the plants with eggs with the wider spectrum of available host plants, systematic samples were selected based on a $50 \times 50 \mathrm{~m}$ grid (Krämer et al., in press). Hence, the number of control plants studied per patch corresponded to the proportional area of each patch. The next plants adjacent to the crossing points in the grid were sampled. For each of the control plants we ascertained the same parameters as for the occupied ones. In total, we selected 63 control plants.

\section{Data analysis}

Each host plant with eggs, regardless of the number of batches, was treated as a single sample in our data set. If data were normally distributed (Komogorov-Smirnov test) and vari-

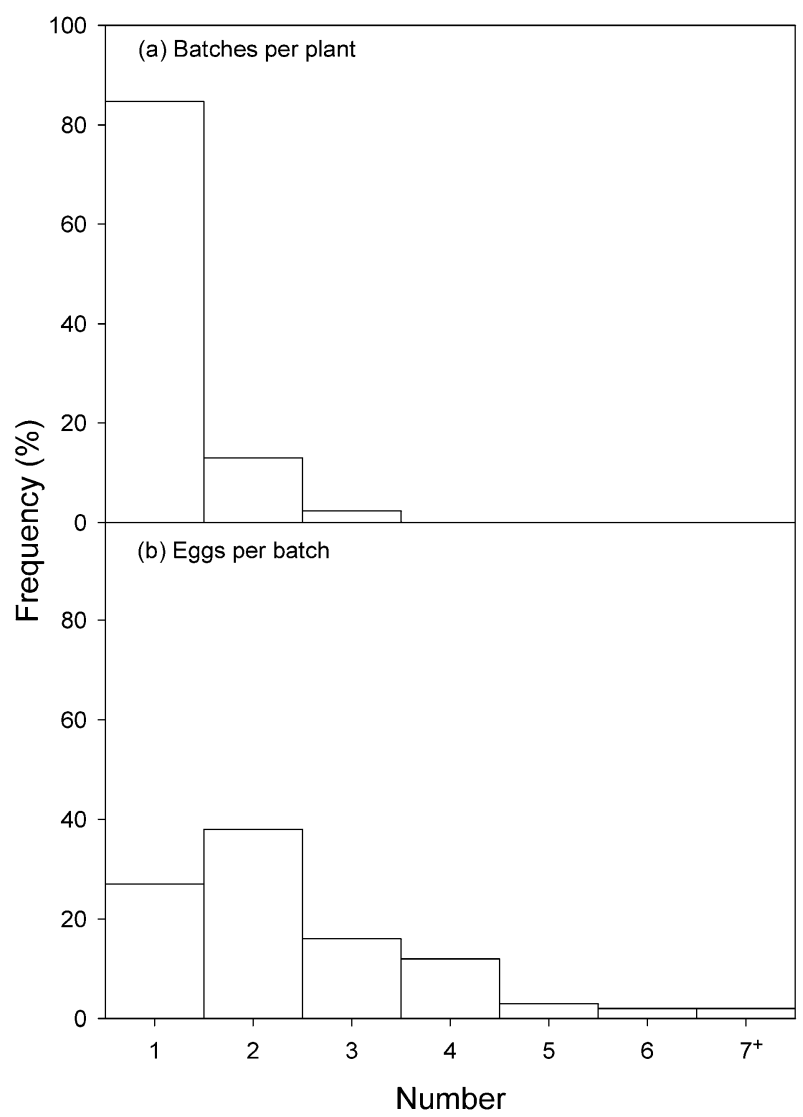

Fig. 2. Number of (a) batches per plant (mean $\pm \mathrm{SE}=1.2 \pm$ $0.1)$ and (b) eggs per batch (mean $\pm \mathrm{SE}=2.4 \pm 0.1)\left(N_{\text {batches }}=\right.$ $\left.148 ; N_{\text {eggs }}=396\right)$.

ances were homogenous (Levene test), parameters for occupied and control host plants were compared using $t$ tests. Otherwise, the Mann-Whitney $U$ test was used. For categorial variables, the likelihood $\chi^{2}$ test was applied. To assess the explanatory power of environmental parameters on the presence of $S$. spini in all the patches studied, we used a binomial generalized linear mixed-effects model (GLMM: lmer, Bates et al., 2008) with a two-vector response variable using R-2.12.1 (R Development Core Team, 2010) (for details see Crawley, 2007). The variable "study area" was set as a random factor. Backward model selection was used to remove non-significant predictor variables. The best model was assessed using the Akaike information criterion (AIC; cf. Zuur et al., 2009). Furthermore, we performed generalized linear models (GLM) (Poisson; each individual patch) and GLMM's (Poisson; all patches) with "patch" as a random factor to examine the relationship between oviposition height and host-plant height. Statistical analyses were performed using SPSS 18 statistical package and R 2.12.1.

TABlE 1. Characteristics of the three study sites in the Diemel Valley. $\mathrm{PPD}=$ regular paddock grazing, irPD $=$ irregular paddock grazing, $\mathrm{ab}=$ abandoned.

\begin{tabular}{lccccccc}
\hline Patch & Main aspect & Area [ha] & Land use & $\begin{array}{c}\text { No. of host } \\
\text { plants }\end{array}$ & $\begin{array}{c}\text { Host } \\
\text { plants/ha }\end{array}$ & $\begin{array}{c}\text { No. of } \\
\text { batches }\end{array}$ & Batches/ha \\
\hline Wiegenfuß (WF) & SW & 7 & rPG & 806 & 125 & 117 & 16.7 \\
Bunter Berg (BB) & SE, S, W & 2.2 & ab & 875 & 367 & 17 & 7.7 \\
Eberschützer Klippen (EK) & N, NW & 2.2 & irPG & 208 & 95 & 14 & 6.4 \\
\hline
\end{tabular}




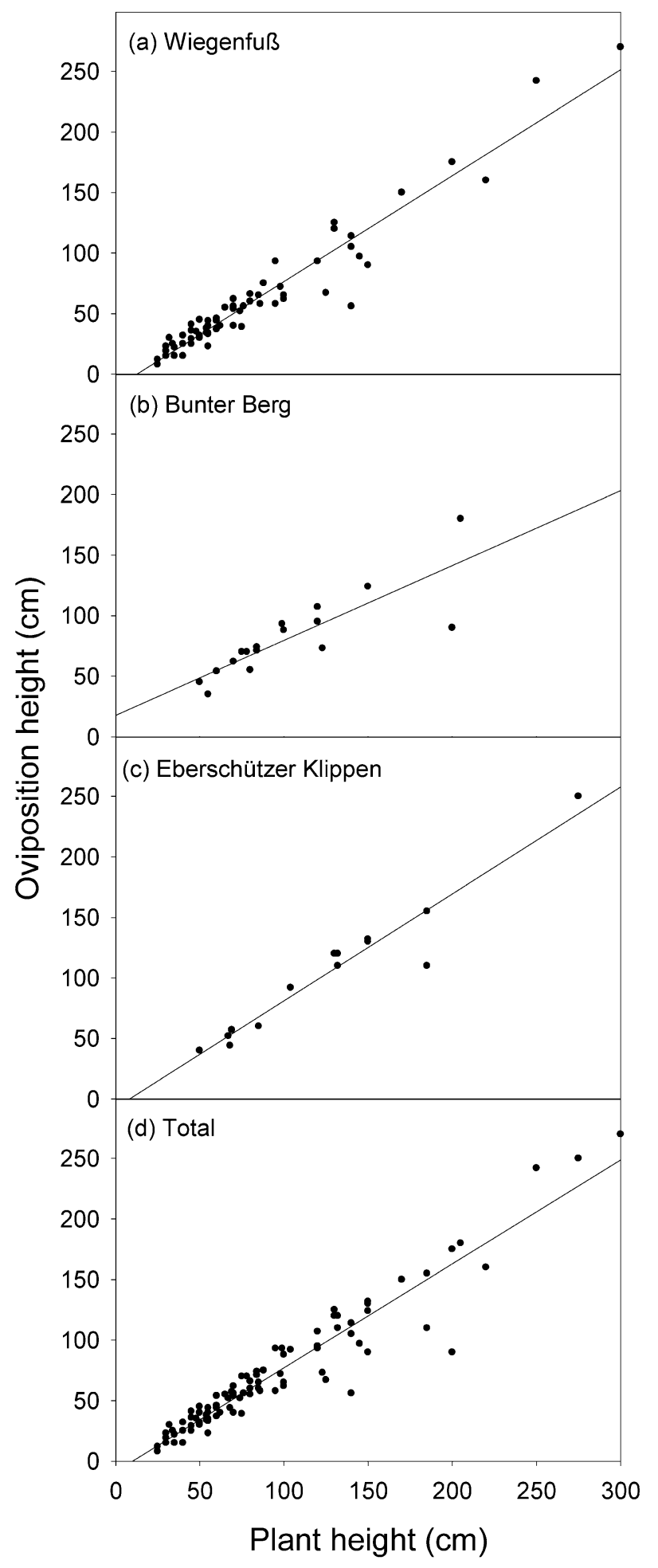

Fig. 3. Relationship between host-plant height and oviposition height at each of the three study sites (a) Wiegenfuß ( $N_{\text {batches }}$ =69), (b) Bunter Berg $\left(N_{\text {batches }}=17\right)$ and (c) Eberschützer Klippen $\left(N_{\text {batches }}=14\right)$, and (d) all patches $\left(N_{\text {batches }}=100\right)$. The relationships were tested using Generalized linear models (GLM) (Poisson, each individual patch) and Generalized linear mixed-effects models (GLMM) with "patch" as a random factor (Poisson, all patches). Statistics of GLM: (a) $Z=16.11$, Pseudo $\mathrm{R}^{2}$ [Nagelkerke] $=0.99, P<0.001$; (b) $\mathrm{Z}=6.02$, Pseudo $\mathrm{R}^{2}$ $\left[\right.$ Nagelkerke] $=0.92, P<0.001 ;$ (c) $\mathrm{Z}=6.02$, Pseudo $\mathrm{R}^{2}$ [Nagelkerke] $=0.99, P<0.001$. Statistics of GLMM: $(\mathrm{d}): \mathrm{Z}=$ 51.25, Pseudo $\mathrm{R}^{2}$ [Nagelkerke] $=1.00, P<0.001$.

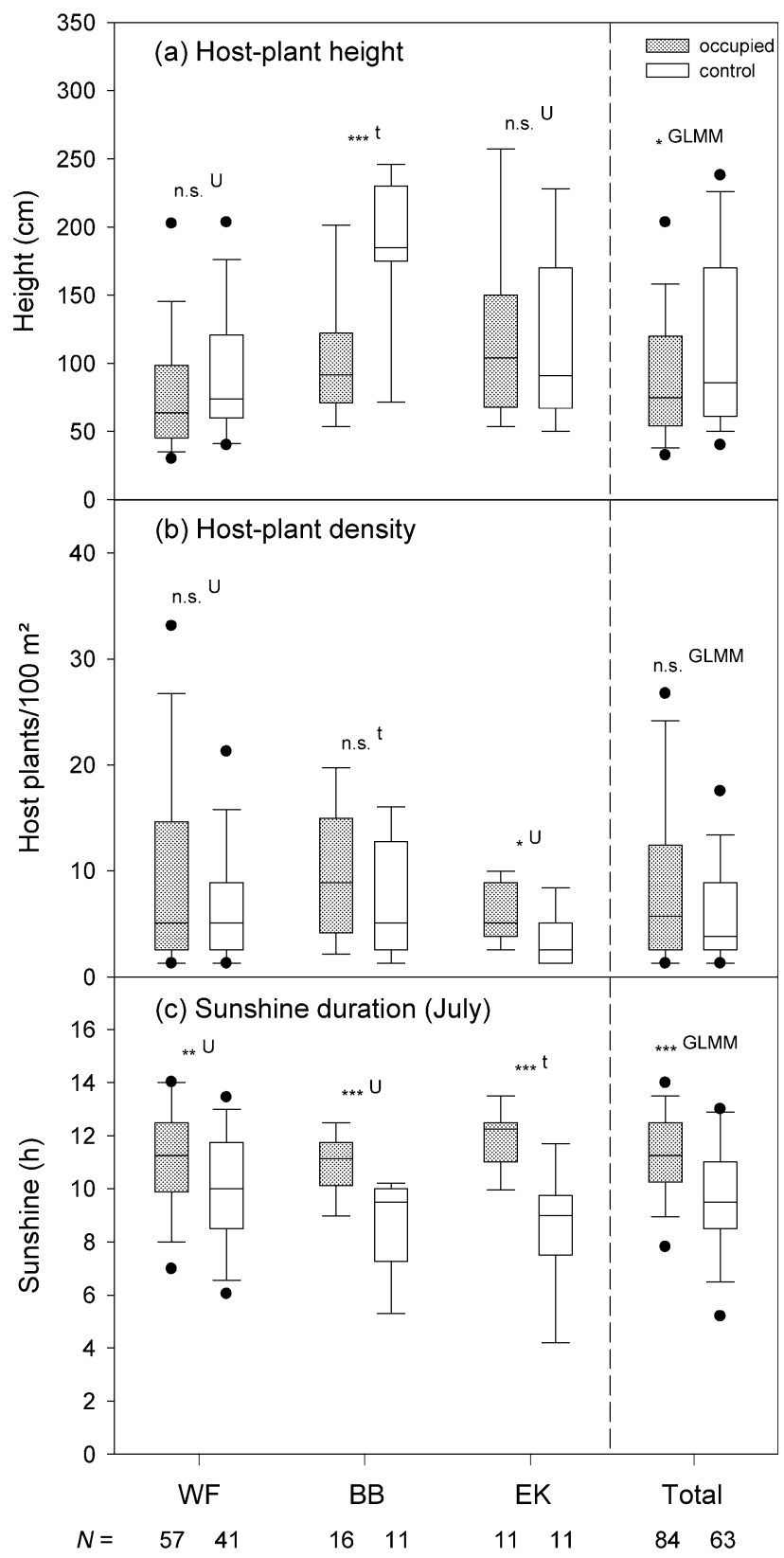

Fig. 4. (a) Host-plant height, (b) host-plant density and sunshine duration (July) on host plants occupied by Satyrium spini and control plants. Box-plots show 5th and 95th percentile (dots), 10th and 90th percentile (whiskers), 25th and 75th percentile limits (boundary of the box) and median (line). The two groups were compared using Mann-Whitney $U$ test $(U), t$ test $(t)$ or Generalized linear mixed-effects models (GLMM), respectively $(\alpha=0.05)$ : n.s. $=$ not significant, $* P<0.05$, $* * P<0.01$, *** $P<0.001$.

\section{RESULTS}

In total we counted 1,889 host plants in the three patches (Table 1). Host-plant densities differed considerably between the patches. Densities of $R h$. cathartica were highest at BB, with 367 plants/ha, followed by WF with 125 plants/ha and EK with 95 plants/ha.

Altogether we found 148 batches containing 396 eggs of S. spini (Fig. 2). Batch density was not related to hostplant density and was highest at WF with 16.7 batches/ha, 
TABle 2. Absolute and relative frequencies (\%) of the nominal variables of the host plants occupied by Satyrium spini and control plants. Slopes of less than $10^{\circ}$ from horizontal were classified as flat (Warren, 1993). Differences between categories were tested using likelihood $\chi^{2}$ test. Differences of $\geq 5$ percentage points between occupied host plants and control plants are indicated in bold type.

\begin{tabular}{|c|c|c|c|c|c|c|c|c|}
\hline \multirow{3}{*}{ Parameter } & \multicolumn{4}{|c|}{ Aspect } & \multicolumn{4}{|c|}{ Orientation of hedge } \\
\hline & \multicolumn{2}{|c|}{$\begin{array}{l}\text { occupied } \\
(N=84)\end{array}$} & \multicolumn{2}{|c|}{$\begin{array}{c}\text { control } \\
(N=63)\end{array}$} & \multicolumn{2}{|c|}{$\begin{array}{l}\text { occupied } \\
(N=45)\end{array}$} & \multicolumn{2}{|c|}{$\begin{array}{c}\text { control } \\
(N=42)\end{array}$} \\
\hline & $\%$ & $N$ & $\%$ & $N$ & $\%$ & $N$ & $\%$ & $N$ \\
\hline North & 1 & 1 & 5 & 3 & 2 & 1 & 24 & 10 \\
\hline North-east & 1 & 1 & 2 & 1 & 11 & 5 & . & . \\
\hline East & 5 & 4 & 2 & 1 & 18 & 8 & 17 & 7 \\
\hline South-east & 5 & 4 & 5 & 3 & 16 & 7 & 10 & 4 \\
\hline South & 25 & 21 & 18 & 11 & 20 & 9 & 26 & 11 \\
\hline South-west & 21 & 18 & 10 & 6 & 22 & 10 & 10 & 4 \\
\hline West & 19 & 16 & 14 & 9 & 9 & 4 & 14 & 6 \\
\hline North-west & 5 & 4 & 3 & 2 & 2 & 1 & . & . \\
\hline Flat & 18 & 15 & 43 & 27 & . & . & . & . \\
\hline $\begin{array}{l}\text { Likelihood } \\
\chi^{2} \text { test }\end{array}$ & & -8 & & & & $=7$ & & \\
\hline
\end{tabular}

followed by BB with 7.7 batches/ha, and EK with 6.4 batches/ha (Table 1). The percentage of batches found within hedges (54\%) and on solitary bushes were similar (46\%) (Table 2).

Usually, there was only one batch of eggs on occupied host plants ( $85 \%$ of the cases); two or three batches per host plant rarely occurred (15\%) (Fig. 2). Eggs were mainly laid in small groups of two up to four eggs ( $66 \%$ of the cases) or singly (27\%). Less frequently, we found batches of five up to twelve eggs (7\%). All batches were attached to smooth-barked, relatively young shoots of $R h$. cathartica. They were never laid on old shoots partly covered with lichens or algae. Batches were predominantly found on the upper surface of twig forks $(76 \%$ of the cases) and less frequently on the under surface of twig forks (16\%), young suckers or thin twigs (8\%).

Oviposition height (range: $8-270 \mathrm{~cm}$ ) was significantly related to host-plant height (Fig. 3). Nevertheless, $80 \%$ of all batches were deposited on small shrubs $(<1.3 \mathrm{~m}$; mean $\pm \mathrm{SE}=91.0 \pm 6.0 \mathrm{~cm})$ near the surface of the ground $(<1$ $\mathrm{m}$; mean $\pm \mathrm{SE}=69.3 \pm 5.0 \mathrm{~cm}$ ). In those patches where most of the host plants were small (WF, EK) the heights of occupied and control plants did not differ (Fig. 4a). In contrast, at $\mathrm{BB}$, where tall and old Rhamnus plants dominated, small plants were preferred. Host-plant density in the vicinity of a host plant influenced the oviposition decision only in the patch with the lowest host-plant density (EK). Here, the likelihood of finding a batch was higher in those areas where the density of Rhamnus was highest (Fig. 4b).

Steep south- and west-facing slopes or south-facing sides of hedges were the preferred oviposition sites, while flat patches or north-facing sides of hedges were avoided (Table 2, Fig. 5). Host plants with a higher potential dura-

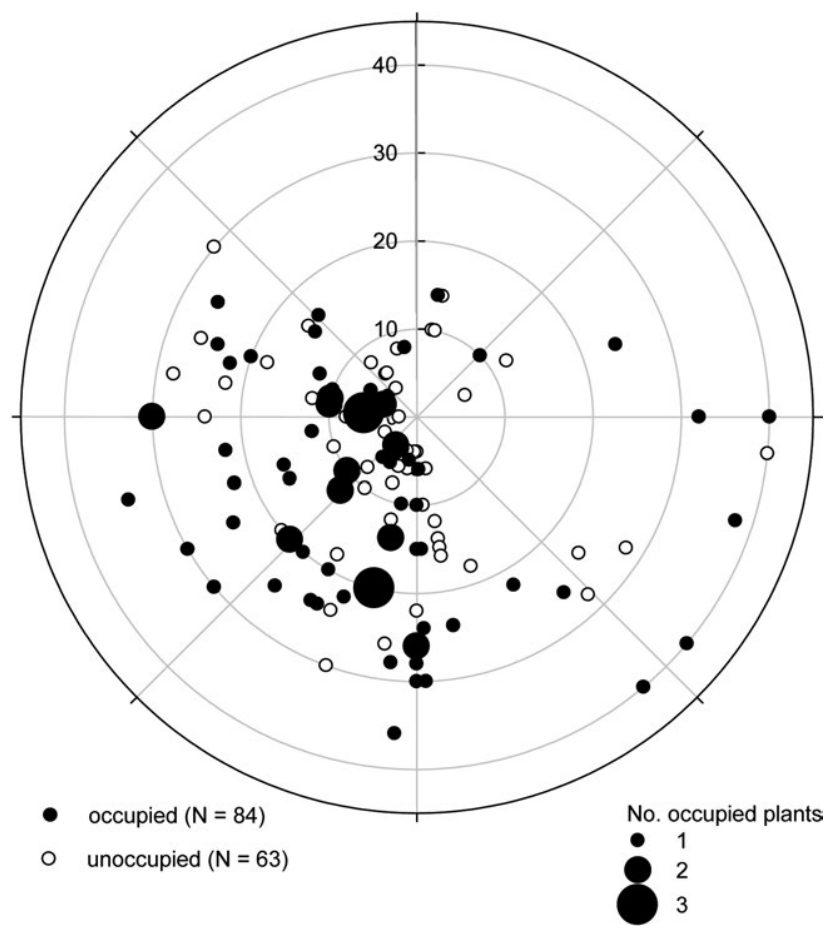

Fig. 5. Polar plot of the aspects and slope of oviposition sites of Satyrium spini $(N=84)$ and control plants $(N=63)$.

tion of sunshine in July were the favoured oviposition sites at all patches (Fig. 4).

Based on the GLMM analysis, the likelihood of a host plant being accepted for oviposition decreased with hostplant height and increased with sunshine duration (Table $3)$.

\section{DISCUSSION}

In this study, where the number of Rhamnus host plants per patch was relatively high, the batch density of $S$. spini was not associated with host-plant density within patches, indicating that other factors are more important for butterfly abundance. Batch density was more than twice as high at the predominantly south-west-facing patch WF than at the two other patches, which were characterized either by mainly northern aspects (EK) or a predominance of tall and old Rhamnus shrubs (BB). Generally, females of $S$. spini preferred to oviposit on small $(<1.3 \mathrm{~m})$, sunexposed shrubs of Rh. cathartica on steep south- and west-facing slopes. Hedges and solitary bushes were used

TABLE 3. Binomial Generalized linear mixed-effects models (GLMM; stepwise-backward selection; random factor: patch) analysis of three predictor variables (cf. Fig. 3) of host plants occupied by Satyrium spini $(N=84)$ and control plants $(N=$ 63). * $P<0.05, * * P<0.01, * * * P<0.001$.

\begin{tabular}{lcccc}
\hline Independent variable & Estimate & $\mathrm{SE}$ & $\mathrm{Z}$ & $P$ \\
\hline (Intercept) & -3.322 & 1.051 & -3.159 & $* *$ \\
Host-plant height & -0.006 & 0.003 & -2.055 & $*$ \\
Sunshine duration (July) & 0.384 & 0.097 & 3.973 & $* * *$ \\
\hline
\end{tabular}

Pseudo $\mathrm{R}^{2}$ [Nagelkerke's] $=0.24$ 
to an equal extent for egg-laying. Batches laid in hedges were mainly on plants on the south side of the hedges. About $80 \%$ of the batches were deposited on the upper surface of a twig fork near the ground $(<1 \mathrm{~m})$.

Concerning the macroclimate, $S$. spini in Central Europe is confined to regions with warm summers (Ebert \& Rennwald, 1991; Beneš et al., 2002). In addition, as this study shows, at the northern limit of its range in Germany, the species prefers those oviposition sites with the warmest conditions at the microhabitat level; i.e. small, sun-exposed shrubs on south- and west-facing slopes and south sides of hedges, and the eggs are laid close to the ground. Even the preferred position on the upper surface of twig forks might be interpreted as another way to maximise heat absorption (cf. Porter, 1992). A warm microclimate has been shown, especially for grass- and herb-feeding butterflies, to be crucial for oviposition near its range margin (García-Barros \& Fartmann, 2009). Similar data for species living on woody plants are rare. However, another hairstreak, Thecla betulae, prefers the microclimatically favoured sides of hedgerows for egglaying near the border of its distribution (Fartmann \& Timmermann, 2006; Merckx \& Berwaerts, 2010).

Despite their preference for small host plants and laying eggs within $<1 \mathrm{~m}$ of the ground, under some conditions, they lay their eggs on taller plants. On the predominately north-facing slopes at EK, the height at which they laid eggs was highest, and this patch was the only one where the heights of occupied host plants did not differ from those of control plants. The temperature near the ground on north-facing slopes only increases very slightly during the day due to the short period for which they are exposed to sunshine and the acute angle of incidence of solar radiation (Stoutjesdijk \& Barkman, 1992). At these sites, taller plants and the higher parts of these plants, where the duration of exposure to sunshine and warming are maximal, should be more favourable for successful development of the eggs. Hermann (2007) also showed that batches can be found at greater heights on taller plants if microclimatic conditions are favourable; i.e. sheltered locations with good heat accumulation.

A preference for areas where the host-plant is abundant is often explained in terms of the ability of females to locate suitable host plants (Dennis, 1984) or availability of sufficient food for caterpillars (Küer \& Fartmann, 2006; Eichel \& Fartmann, 2008). However, for S. spini the latter should not be a limiting factor as the egg load per plant was low. Even on small Rh. cathartica bushes there are sufficient leaves for the few larvae. In contrast, host-plant density might be more important where host plants are generally very rare and females spend a lot of time searching for host plants. In such patches, the visual apparency of a group of host plants may increase the likelihood of their discovery by a female and hence egg occupancy should also increase. This was possibly the case at EK.

\section{Implications for conservation}

Late successional stages of calcareous grasslands, such as those in which shrubs are abundant, provide the most favourable conditions for Rh. cathartica (Oberdorfer, 2001). However, S. spini prefers mid-successional stages of calcareous grasslands, where it lays eggs mainly on small, Rhamnus plants fully exposed to sunshine growing on steep south- or west-facing slopes. The survival of these habitats depend on regular management (cf. Stuhldreher et al., 2012). For optimal land use we recommend traditional rough grazing by sheep and goats, which creates open grasslands with small Rhamnus plants. That grazing favours $S$. spini is indicated by the fact that WF, which was where the highest batch density was recorded, was the only patch studied that was regularly grazed. In line with this, Hermann (2007) mentions that S. spini habitats are often grazed by sheep and eggs frequently occur on browsed host plants. The loss of eggs due to browsing seems to be low. After one week of paddock grazing by goats in September, of the 84 batches, which were recorded at WF prior to grazing, 70 batches $(83 \%)$ were still present (personal observation). Moreover, rough grazing is also known to favour other target insects occurring in the calcareous grasslands in the Diemel Valley (Fartmann, 2006; Anthes et al., 2008; Eichel \& Fartmann, 2008; Poniatowski \& Fartmann, 2010; Krämer et al., in press).

In addition, we recommend the rotational cutting of a quarter of the shrubs every fourth year in tall hedges growing on calcareous grasslands (cf. Thomas, 1974). Larvae of $S$. spini are already able to feed on one-year-old suckers (Koschuh et al., 2005), and young suckers generally have a high rate of batch occupancy (Hermann, 2007). Coppicing is also known to favour other shrubfeeding butterflies, such as Thecla betulae (Fartmann \& Timmermann, 2006) or Iphiclides podalirius (Steiner et al., 2007). In contrast, mulching or removing all the shrubs from a patch can be harmful. This is especially the case where the patches are small as it can result in a subpopulation becoming extinct (pers. observ.; cf. Ebert \& Rennwald, 1991).

Coppiced woodlands were formerly widespread in the Diemel Valley, but the practice was ceased during the last century (Fartmann, 2004, 2006). The reintroduction of this way of managing forests, particularly those adjacent to calcareous grasslands, would favour S. spini (Beneš et al., 2002, 2003) and other threatened species of butterfly (e.g. Hameris lucina: Fartmann, 2006; Anthes et al., 2008). Even if regular coppicing is not possible, clear cutting is an alternative as it creates new habitats for S. spini that remain suitable for many years (Hermann, 2007).

ACKNOWLEDGEMENTS. We are very grateful to G. Hermann (Hildrizhausen) and an anonymous reviewer for valuable comments on an earlier version of the manuscript. The Akademie für ökologische Landeserforschung e.V. partly funded this study.

\section{REFERENCES}

Anthes N., Fartmann T. \& Hermann G. 2008: The Duke of Burgundy butterfly and its dukedom: larval niche variation in Hamearis lucina across Central Europe. - J. Insect Conserv. 12: 3-14. 
Bates D., Maechler M. \& DAi B. 2008: Ime4: Linear MixedEffects Models Using S4 Classes. R Package Version 0.999375-28. http://lme4.r-forge.r-project.org

Benes J., KepKa P. \& Konvicka M. 2003: Limestone quarries as refuges for European xerophilous butterflies. - Conserv. Biol. 17: 1058-1069.

Benes J., Konvicka M., Dvorak J., Fric Z., Haveld Z., Pavlicko A., Vrabec V. \& Weidenhoffer Z. (eds) 2002: Motýli České republiky: Rozšireni a ochrana [Butterflies of Czech Republic: Distribution and Conservation] I. SOM, Prague, pp. $1-478$.

Crawley M.J. 2007: The R Book. Wiley, Chichester, pp. 1-942.

Dennis R.L.H. 1984: Egg-laying sites of the Common Blue butterfly, Polyommatus icarus (Rottemburg) (Lepidoptera: Lycaenidae): the edge effect and beyond the edge. - Entomol. Gaz. 35: 85-93.

Dennis R.L.H., Hodgson J.G., Grenyer R., Shreeve T.G. \& Roy D.B. 2004: Host plants and butterfly biology. Do host-plant strategies drive butterfly status? - Ecol. Entomol. 29: 12-26.

DenNis R.L.H., Shreeve T.G. \& Van Dyck H. 2006: Habitats and resources: the need for a resource-based definition to conserve butterflies. — Biodivers. Conserv. 15: 1943-1966.

Ebert G. \& Rennwald E. 1991: Die Schmetterlinge BadenWürttembergs. Band 2, Tagfalter II. Ulmer, Stuttgart, 535 pp.

Eichel S. \& FARTMANN T. 2008: Management of calcareous grasslands for Nickerl's fritillary (Melitaea aurelia) has to consider habitat requirements of the immature stages, isolation, and patch area. - J. Insect Conserv. 12: 677-688.

FARTMANN T. 2004: Die Schmetterlingsgemeinschaften der Halbtrockenrasen-Komplexe Diemeltales. Biozönologie von Tagfaltern und Widderchen in einer alten Hudelandschaft. Abh. Westf. Mus. Naturk. 66: 1-256.

FARTMANN T. 2006: Oviposition preferences, adjacency of old woodland and isolation explain the distribution of the Duke of Burgundy butterfly (Hamearis lucina) in calcareous grasslands in central Germany. - Ann. Zool. Fenn. 43: 335-347.

FARTMANN T. \& Hermann G. 2006: Larvalökologie von Tagfaltern und Widderchen in Mitteleuropa - von den Anfängen bis heute. In Fartmann T. \& Hermann G. (eds): Larvalökologie von Tagfaltern und Widderchen in Mitteleuropa. Abh. Westf. Mus. Naturk. 68 (3/4): 11-57.

Fartmann T. \& Timmermann K. 2006: Where to find the eggs and how to manage the breeding sites of the Brown Hairstreak (Thecla betulae (Linnaeus, 1758)) in Central Europe. - Nota Lepid. 29: 117-126.

García-Barros E. \& Fartmann T. 2009: Oviposition sites. In Settele J., Shreeve T., Konvicka M. \& Van Dyck H. (eds): Ecology of Butterflies in Europe. Cambridge University Press, Cambridge, pp. 29-42.

Grime J.P., Hodgson J.G. \& Hunt R. 2007: Comparative Plant Ecology, a Functional Approach to Common British Species. Castlepoint Press, Dalbeattie, 748 pp.

Hermann G. 2007: Tagfalter suchen im Winter - Zipfelfalter, Schillerfalter und Eisvögel [Searching for Butterflies in Winter - Hairstreaks, Purple Emperos, Poplar Admirals \& White Admirals.] Books on Demand. Norderstedt, 224 pp.

Kahmen S., Poschlod P. \& Schreiber K.-F. 2002: Conservation management of calcareous grasslands. Changes in plant species composition and response of functional traits during 25 years. - Biol. Conserv. 104: 319-328.

Kadlec T., Vrba P., Kepka P., Schmitt T. \& Konvicka M. 2010: Tracking the decline of the once-common butterfly: delayed oviposition, demography and population genetics in the hermit Chazara briseis. - Anim. Conserv. 13: 172-183.

Koschun A., Savas V. \& Gepp J. 2005: Winter-Eifunde von Zipfelfalterarten (Lepidoptera: Lycaenidae) in Graz und
Umland (Steiermark, Österreich). - Naturschutz Landschaftspl. 37(2): 46-53.

Kudrna O. 2002: Distribution Atlas of European Butterflies. Oedippus, Schweinfurt, 344 pp.

Krämer B., Kämpf I., Enderle J., Poniatowski D. \& Fartmann $\mathrm{T}$. in press: Microhabitat selection in a grassland butterfly: a trade-off between microclimate and food availability. $-J$. Insect Conserv.

KÜER A. \& FARTMAnN T. 2005: Prominent host plants are preferred: microhabitat preferences of Maculinea alcon ([Denis \& Schiffermüller], 1775) in Northern Germany (Lycaenidae). — Nota Lepid. 27: 309-319.

Merckx T. \& Berwaerts K. 2010: What type of hedgerows do Brown hairstreak (Thecla betulae L.) butterflies prefer? Implications for European agricultural landscape conservation. - Insect Conserv. Diver. 3: 194-204.

Möllenbeck V., Hermann G. \& Fartmann T. 2009: Does prescribed burning mean a threat to the rare satyrine butterfly Hipparchia fagi? Larval-habitat preferences give the answer. - J. Insect Conserv. 13: 77-87.

OBerdorfer E. 2001: Pflanzensoziologische Exkursionsflora für Deutschland und angrenzende Gebiete. Ulmer, Stuttgart, $1051 \mathrm{pp}$.

Poniatowski D. \& Fartmann T. 2010: What determines the distribution of a flightless bush-cricket (Metrioptera brachyptera) in a fragmented landscape? - J. Insect Conserv. 14: 637-645.

PORTER K. 1992: Eggs and egg-laying. In Dennis R.L.H. (ed.): The Ecology of Butterflies in Britain. Oxford University Press, Oxford, pp. 46-72.

R Development Core Team 2010: $R$ : A Language and Environment for Statistical Computing. http://www.r-project.org

ReInHARDT R. \& Bolz R. (eds) in press: Rote Liste der Tagfalter (Rhopalocera) (Lepidoptera: Papilionoidea et Hesperioidea). - Natursch. Biol. Vielfalt 70.

Roy D.B. \& Thomas J.A. 2003: Seasonal variation in the niche, habitat availability and population fluctuations of a bivoltine thermophilous insect near its range margin. - Oecologia 134: 439-444.

SHrEEVE T.G. 1986: Egg-laying by the speckled Wood butterfly (Pararge aegeria): The role of female behaviour, host plant abundance and temperature. - Ecol. Entomol. 11: 229-236.

Ssymank A., Hauke U., RüCKRIEM C. \& Schröder E. 1998: Das europäische Schutzgebietssystem NATURA 2000. BfNHandbuch zur Umsetzung der Fauna-Flora-Habitat-Richtlinie und der Vogelschutz-Richtlinie. - Schriftenr. Landschaftspfl. Natursch. 53: 1-560.

StefFan-Dewenter I. \& TscharntKe T. 2000: Butterfly community structure in fragmented habitats. - Ecol. Lett. 3: 449-456.

Steiner R., Hermann G. \& Settele J. 2007: Ökologie einer aussterbenden Population des Segelfalters Iphiclides podalirius (Linnaeus, 1758). [Ecology of an almost extinct population of the Scarce Swallowtail Iphiclides podalirius (Linnaeus, 1758).] - Invertebr. Ecol. Conserv. Monogr. 1: 171 pp.

StoutJesdiJK P. \& Barkman J.J. 1992: Microclimate, Vegetation and Fauna. Opulus Press, Uppsala, 216 pp.

Stuhldreher G., Villar L. \& FartmanN T. 2012: Inhabiting unusually warm microhabitats and risk-spreading as strategies of a phytophagous insect to survive in common pastures of the Pyrenees. - Eur. J. Entomol. 109: 527-534.

ThOMAs J.A. 1974: Factors Influencing the Numbers and Distribution of the Brown Hairstreak, Thecla betulae L. (Lepidoptera, Lycaenidae) and the Black Hairstreak, Strymonidia pruni L. (Lepidoptera, Lycaenidae). $\mathrm{PhD}$ thesis, University Leicester, 288 pp. 
THOMAs J.A. 1993: Holocene climate changes and warm manmade refugia may explain why a 6th of British butteflies possess unnatural early-succesional habitats. - Ecography 16: 278-284.

Thomas J.A., Simcox D.J., Wardlaw J.C., Elmes G.W., Hochberg M.E. \& Clarke R.T. 1998: Effects of latitude, altitude and climate on the habitat and conservation of the endangered butterfly Maculinea arion and its Myrmica ant hosts. J. Insect Conserv. 2: 39-46.

Thomas J.A., Bourn N.A.D., Clarke R.T., Stewart K.E., Simcox D.J., Pearman G.S., Curtis R. \& Goodger B. 2001: The quality and isolation of habitat patches both determine where butterflies persist in fragmented landscapes. - Proc. R. Soc. Lond. 268: 1791-1796.

Thomas J.A., Telfer M.G., Roy D.B., Preston C.D., Greenwood J.J.D., Asher J., Fox R., Clarke R.T. \& Lawton J.H. 2004: Comparative losses of British butterflies, birds, and plants and the global extinctioncrisis. - Science 303: 1879-1881.

Tonne F. 1954: Besser Bauen mit Besonnungs- und TageslichtPlanung. Hoffmann, Schorndorf, 41 pp.

VAN DIJK G. 1991: The status of semi-natural grasslands in Europe. In Goriup P.D., Batten L.A. \& Norton J.A. (eds): The Conservation of Lowland Dry Grasslands in Europe. Joint Nature Conservation Council, Peterborough, pp. 15-36.

VAN SWaAy C. 2002: The importance of calcareous grasslands for butterflies in Europe. - Biol. Conserv. 104: 315-318.

Van Swaay C. \& Warren M. (eds) 2003: Prime Butterfly Areas in Europe: Priority Sites for Conservation. National Reference Centre for Agriculture, Nature and Fisheries, Ministry of
Agriculture, Nature Management and Fisheries, Wageningen, $695 \mathrm{pp}$.

Van Swaay C., Warren M. \& Lois G. 2006: Biotope use and trends of European butterflies. - J. Insect Conserv 10: 189-209.

WallisDeVries M.F., Poschlod P. \& Willems J.H. 2002: Challenges for the conservation of calcareous grasslands in northwestern Europe: integrating the requirements of flora and fauna. - Biol. Conserv. 104: 265-273.

WARREN M.S. 1993: A review of butterfly conservation in central southern Britain: II. Site management and habitat selection of key species. - Biol. Conserv. 64: 37-49.

WatT W.B. \& BogGs C.L. 2003: Synthesis: butterflies as model systems in ecology and evolution - present and future. In Boggs C.L., Watt W.B. \& Ehrlich P.R. (eds): Butterflies Ecology and Evolution Taking Flight. University of Chicago Press, Chicago, pp. 603-613.

WeIDEmann H.J. 1982: Gedanken zum Artenschutz. 2. Über Mängel der herkömmlichen Lepidopterologie - ein Liebhaberentomologe gibt Denkanstösse. - Entomol. Z. 92(8): 97-111.

WiLlEMS J.H. 1990: Calcareous grasslands in Continental Europe. In Hillier H., Walton D.H.W. \& Wells D.A. (eds): Calcareous Grasslands. Ecology and Management. Bluntisham Books, Bluntisham, pp. 3-10.

Zuur A.F., Ieno E.N., Walker N.J., Saveliev A.A. \& Smith G.M. 2009: Mixed Effects Models and Extensions in Ecology with $R$. Springer, New York, 574 pp.

Received May 14, 2012; revised and accepted July 2, 2012 